Int. J. Electrochem. Sci., 15 (2020) 12030 - 12040

International Journal of

ELECTROCHEMICAL

SCIENCE

$\underline{\text { WWW.electrochemsci.org }}$

\title{
A study of $\mathrm{La}_{1-\mathrm{x}} \mathrm{Sr}_{\mathrm{x}} \mathrm{CoO}_{3-\delta} \mathrm{SOFC}$ Cathodes using Cone-shaped Electrodes and EIS
}

\author{
K. Kammer Hansen \\ Kammer Consulting, Skelbækparken 91, DK-3650 Ølstykke, Denmark \\ E-mail: kkha@dtu.dk
}

doi: $10.20964 / 2020.12 .41$

Received: 17 August 2020 / Accepted: 2 October 2020 / Published: 31 October 2020

\begin{abstract}
Six strontium substituted lanthanum cobaltite's $\left(\mathrm{La}_{1-\mathrm{x}} \mathrm{Sr}_{\mathrm{x}} \mathrm{CoO}_{3-\delta}, \mathrm{x}=0,0.05,0.15,0.25,0.35\right.$ and 0.5$)$ were synthesized using the glycine-nitrate process. The cobaltites were characterized with powder XRD, dilatometry, 4-point DC conductivity measurements and electrochemical impedance spectroscopy on cone-shaped electrodes using a $\mathrm{Ce}_{1.9} \mathrm{Gd}_{0.1} \mathrm{O}_{1.95}$ electrolyte. All the compounds were single phased belonging to hexagonal crystal system. The thermal expansion coefficient decreases until a strontium content of $15 \%$ where after it increases. The conductivity increased for temperatures below $600{ }^{\circ} \mathrm{C}$ with increasing strontium content. At higher temperatures the conductivity increased until the strontium content reached $15 \%$, where after it began to decrease. It was shown that the activity of the cobaltite's were strongly dependent on the strontium content. The highest activity, towards the reduction of oxygen, was found for the strontium rich composition, $\mathrm{La}_{0.5} \mathrm{Sr}_{0.5} \mathrm{CoO}_{3-\delta}$, with an area specific resistance of 0.92 $\Omega \mathrm{cm}^{2}$ at $600^{\circ} \mathrm{C}$. It was concluded that the activity of the cobaltites towards the reduction of oxygen is determined mainly by the oxide ionic conductivity.
\end{abstract}

Keyword: SOFC; Cobaltite's; Oxygen reduction; Cones

\section{$\underline{\text { FULL TEXT }}$}

(C) 2020 The Authors. Published by ESG (www.electrochemsci.org). This article is an open access article distributed under the terms and conditions of the Creative Commons Attribution license (http://creativecommons.org/licenses/by/4.0/). 